\title{
Turnaround Strategy of Financially Distressed Company: Empirical Study of Manufacturing Company Listed on Indonesia Stock Exchange
}

\section{Lintang Venusita and Mike Nur Wijayanti}

Accounting Departement, Faculty of Economy, State University of Surabaya, Surabaya, Indonesia

\section{Abstract}

The purpose of this article is to examine financially distressed companies in Indonesia and their restructuring strategies. The strategies we observed are merger and acquisition, CEO turnover, and employee lay-off. This study tries to identify the difference of abnormal return and average abnormal return before and after the strategies announcement. This study uses event study and market model method. Through purposive sampling, 30 companies were categorized as financially distressed

Corresponding Author: Lintang Venusita Ivenusita@gmail.com

Received: 29 January 2019 Accepted: 27 February 2019 Published: 24 March 2019

Publishing services provided by Knowledge E

(c) Lintang Venusita and Mike Nur Wijayanti. This article is distributed under the terms of the Creative Commons

Attribution License, which permits unrestricted use and redistribution provided that the original author and source are credited.

Selection and Peer-review under the responsibility of the $3 r d$ ICEEBA Conference Committee. using Altman $z$-score in the period of 2009-2011, and 14 events were identified as turnaround strategies in the period of 2012-2017 as the sample. The observation period was 10 days prior to, 1 day during, and 10 days following the strategies announcement. The research variables are abnormal return assessed using One Sample $t$-test and average abnormal return assessed using Paired Sample $t$-test. It was found out that there are three events of merger and acquisitions, five events of CEO turnover, and six events of employee lay-off. The result shows that there is a positive significant difference abnormal return in the merger and acquisition announcement and no significant difference abnormal return for CEO Turnover and Employee Lay-off. The second result shows that there are no significant differences in the average abnormal return of stock before and after merger and acquisition, CEO turnover, and employee lay-off.

Keywords: turnaround strategies, financial distress, abnormal return

\section{Introduction}

Changes in the economic conditions often affect financial performance, for small, medium and large companies. Management who are not ready for changes in economic conditions will face the possibility of a decline in financial performance and the worst experience the bankruptcy (Almilia \& Kristijadi, 2014). High market competition will certainly make it difficult for the company to maintain its existence. Companies are 
required to develop innovation, improve overall performance, and expand business in order to stay in competition. The level of ability of a company is largely determined by the performance of the company itself. In this case, companies that are unable to compete will eventually be evicted from the market and will experience bankruptcy (Suhfriahtiningsih, 2017).

The bankruptcy of a company is characterized by a stage of decline in financial conditions or commonly referred to as financial distress can be experienced by various large or small companies from various industrial sectors (Suhfriahtiningsih, 2017). Financial distress is defined as the stage of decreasing financial conditions that occur before bankruptcy or liquidation (Platt \& Platt, 2002). The ability to indicate financial distress conditions allows companies to anticipate through various programs/business plans to minimize the impact (Vestari \& Farida, 2013). The management who can detect financial distress earlier, will be able to act actively to analyze the causes of financial distress and implement the right turnaround strategy, will be far more able to control these conditions (Suhfriahtiningsih, 2017).

Turnaround strategy is defined as a reversal of the direction of the company from a decrease in performance (Schendel, Patton, \& Riggs, 1976). Turnaround is a process to bring a company from a poor performance situation to a situation of good sustained performance. Successful turnaround is a complex process that includes a combination of environmental factors, internal resources, relevant corporate strategies at various stages of performance degradation, which results in improved financial performance. Companies need strategies that are indeed effective to achieve recovery or turnaround success (O’Neill, 1986, Schendel, Patton, \& Riggs, 1976). There are various turnaround strategies implemented to reverse the loss situation in profit circumstances (Pearce II \& Robbins, 1994), including reducing operating costs through reducing labor, selling assets, reducing business units and exchanging management (Pearce II \& Robbins, 1993).

The success of a company is reflected in the value of the company. For companies that go public, the value of the company can be observed from its stock price. Share prices always reflect the value of the company (Telaumbanua \& Sumiyana, 2008). Share prices are strongly influenced by fundamental and technical factors. The consideration of investors to make a decision to invest in stocks is information about the condition of the company. An information can be said to have value for investors if the information provides a reaction to conduct transactions in the capital market. This can be seen from the abnormal return which is one indicator that can be used to see the current market situation (Jogiyanto, 2010). 
Kam et al. (2010), examines how the market reacts to the implementation of turnaround strategies applied by companies experiencing financial distress in 2 companies, namely government companies and private companies. Researchers pay attention to 4 strategies namely mergers and acquisitions, asset sales, management restructuring and debt restructuring. The results show that the strategy of mergers and acquisitions has the highest impact on market reaction. Research conducted by Ashayeri et al. (2014) found that downsizing increases the long-term effectiveness of resources in companies that experience bankruptcy. Management needs to pay special attention to applying downsizing if bankruptcy pressure is to balance short-term survival and longterm prosperity of the company. In downsizing the action of terminating employees is an action taken by the company in overcoming a poor operating performance (Lin et al. 2008).

Maheshwari, (2000) explains that the turnaround process begins with changes in top management. This consistently shows that the commitment of leadership has increased and there are efforts to restore the trust of stakeholders. Research conducted by Chan, (1993) found that 10 out of 10 cases exist, companies choose to replace their CEO. Gopinath, (1991) also found that 20 of the 22 companies that made turnarounds applied CEO turnover to their companies, this was confirmed by a study by Gilson, 1990 which found that companies tended to do CEO turnovers in companies that experienced financial distress.

This article examines the restructuring and subsequent performance of financially distressed manufacturing companies in Indonesia. It looks at the distress resolution strategies they employed and the valuation effects of their restructuring announcements. The strategies we observed are merger \& acquisition, CEO turnover and employee lay-off. This study tries to identify the difference of abnormal return and average abnormal return before and after the strategies announce.

\section{Literature Review}

\subsection{Financial distress}

Financial distress is the initial stages before the company go through bankruptcy or liquidity. Financial distress can be known by a poor financial performance of company, technically bankruptcy always begins with financial distress. Financial distress can be described from two extreme points, namely short-term liquidity difficulties to insolvency. Short-term financial distress are usually take a short-term period, but can develop into 
severe and get worst. Indicators of financial distress can be seen from cash flow analysis, company strategy analysis, and company financial statements (Mamduh \& Halim, 2007).

\subsection{Turnaround strategy}

Turnaround strategy is the process of reversing the direction of the company from poor performance to a better performance (Schendel, et al. 1976). A corporate turnaround may be defined simply as the recovery of a company's economic performance following an existence-threatening decline. A successful turnaround is a complex process which includes a combination of environmental factors, internal resources, relevant corporate strategies at various stages of performance degradation, which results in improved financial performance or recovery. A company need to acknowledge and identify it's problem first and then implement the problem-solving strategy (Arogyaswamy et al., 1995).

\subsection{Mergers and acquisitions}

There are three ways to deal with financial distress. First, the company change all assets into cash and collecting the remaining receivables, where the cash will be divided equally to creditors and investors. Second, do mergers and acquisitions and the third is by taking a legal action like arbitration. Mergers and acquisitions are one of the strategies pursued by companies to maintain and improve financial performance (Mutamimah, 2009). Mitchell \& Mulherin (1996) found out that mergers provide value to investors due to the merger of two companies. This means that in general mergers and acquisitions provide benefits and have a positive impact on joint companies. Gugler et al. (2003) concludes that mergers generally result in a significant increase in profits in joint companies, de Young et al. (2009) also said that mergers and acquisitions in the financial sector have a positive effect on company performance. Auqie (2013) states that the announcement of mergers and/or acquisitions in companies listed on the Indonesia Stock Exchange will influence the market reaction.

$\mathrm{H}_{1 a}$ : There is a significant market reaction around the date of the announcement of mergers $\&$ acquisitions in financial distress companies.

\subsection{CEO turnover}

Actions taken by companies that experience a decline in performance are determined from the policy of the leader. In improving the condition of the company, changes in 
the senior management team are important steps to be taken to improve stakeholders' trust (Arogyaswamy et al. 1995). The reason why some companies experience success and some experience failure is no longer only in the strategy applied, but also in the management of the company, on the other hand the manager is also able to be the cause of a company's decline (Whiting \& Miller, 2008). Research conducted by Hofer, (1980) found that most of the successful turnaround applied turnover to company management.

Maheshwari, (2000) explains that the turnaround process begins with changes in top management. This consistently shows that the commitment of leadership has increased and there are efforts to restore the trust of stakeholders. New management is considered to be able to restore stakeholder trust (Maheshwari, 2000) and can bring new knowledge, abilities and perspectives in the company (Grinyer et al., 1990; Tourtellot, 2004) Research conducted by Chan, (1993) found that 10 out of 10 cases exist, companies choose to replace their CEO. Gilson, (1990) also found that 20 of the 22 companies that made turnarounds applied CEO turnover to their companies, this was confirmed by a study by Gilson, (1990) which found that companies tended to do CEO turnovers in companies that experienced financial distress.

Research in the United Kingdom conducted by Dahya \& McConnell (2005) found that investors in the UK were positive for the announcement of CEO changes because they considered CEO turnover as good news. At the other hand, Dedman \& Lin, (2002) stated that markets react negatively to announcements. The results of research in Australia conducted by Suchard et al. (2001) showed the market reacted negatively to the announcement of CEO turnover. Meanwhile, investors in Japan reacted positively to the announcement of CEO turnover (Kang \& Shivdasani, 1996).

$\mathrm{H}_{1 b}$ : There is a significant market reaction around the date of the announcement of management turnover (CEO Turnover) in financial distress companies.

\subsection{Downsizing}

Operational restructuring has been considered as one of the important turnaround strategies for a company when facing bankruptcy pressure (Lin et al. 2008). In companies that experience losses, the first step is to control costs to return to gain some profit. Cutting labor costs, production costs, sales and administrative costs, R \& D spending is a common step in restructuring companies (Denis \& Kruse, 2000). Brain \& Co's survey, 2013 by interviewing 1,208 executives, resulted in 60\% of executives choosing to downsize as a management tool when the company experienced a decline (Santana et al. 2017). 
Ashayeri et al. (2014) found that downsizing increases the long-term effectiveness of resources in companies that experience bankruptcy. Management needs to pay more attention to applying downsizing if there is a bankruptcy pressure to balance shortterm survival and long-term prosperity of the company. More specifically, the solution to downsizing companies that face the risk of bankruptcy can prevent a liquidity crisis, and provide guarantees in the fulfillment of debt to creditors. Downsizing such as employee lay-off is an actions taken by the company in overcoming poor operating performance (Lin et al. 2008).

$\mathrm{H}_{1 c}$ : There is a significant market reaction around the date of the announcement of employee lay-off (downsizing) in financial distress companies

Based on the $H_{1}$, the $H_{2}$ is needed to determine the average difference in each strategy

$\mathrm{H}_{1 c}$ : There is a differences in average abnormal returns after and before the announcement of mergers \& acquisitions, employee lay-off (downsizing), management turnover (CEO Turnover) in financial distress companies.

\section{Research Methodology}

This study uses a quantitative approach with the type of research used is event study. The type of data in this study is secondary data. The data in this research were obtained through the Indonesia Stock Exchange website accessed through http://www.idx.co.id and sahamok site accessed through www.sahamok.com.

\subsection{Sample selection}

The population in this study is a manufacturing company listed on the Indonesia Stock Exchange that experienced financial distress 2 years in a row during 2009-2011. The sampling criteria are categorized as financial distress manufacturing companies based on Altman z-score that provide information regarding the announcement of turnaround strategies, namely mergers \& acquisitions, CEO turnover and downsizing (reduction of employees) during 2012-2017. After eliminating companies that do not make announcements of turnaround strategies from the population, a sample of research can be seen in Table 1. As for the list of companies that provide information regarding the announcement of turnaround strategies, namely mergers \& acquisitions, CEO turnover and employee lay-off (downsizing) can be seen in Table 2. 
TABLE 1: Population and sample.

\begin{tabular}{|l|c|}
\hline Result & Total \\
\hline Manufacturing companies 2009-2011 & 124 \\
\hline Manufacturing companies with uncomplete data & 11 \\
\hline Manufacturing companies categorized FD & 30 \\
\hline Manufacturing companies categorized Grey Area & 48 \\
\hline Manufacturing companies categorized Non-FD & 35 \\
\hline Research population & 30 \\
\hline Research sample & 14 \\
\hline
\end{tabular}

TABLE 2: Date of announcement strategy.

\begin{tabular}{lll} 
Code & Turnaround Strategy & Date of Announcement \\
TKIM & Merger \& Acquisition & 10 September 2013 \\
\hline AISA & Merger \& Acquisition & 14 May 2014 \\
MYRX & Merger \& Acquisition & 10 June 2014 \\
ERTX & CEO Turnover & 23 April 2012 \\
ADES & CEO Turnover & 25 June 2013 \\
\hline INAI & CEO Turnover & 24 June 2014 \\
\hline KBRI & CEO Turnover & 15 August 2017 \\
INKP & CEO Turnover & 13 June 2017 \\
\hline ARGO & Employee Lay-Off & 15 September 2015 \\
POLY & Employee Lay-Off & 29 October 2015 \\
\hline PICO & Employee Lay-Off & 12 November 2015 \\
TKIM & Employee Lay-Off & 30 September 2016 \\
\hline INKP & Employee Lay-Off & 12 May 2017 \\
\hline AISA & Employee Lay-Off & 20 December 2017
\end{tabular}

\subsection{Measurement of financial distress}

Determination of companies experiencing financial distress is by measuring financial performance by using discriminant analysis (Altman, 2000), with the following formula:

$$
Z=0.717 X_{1}+0.847 X_{2}+3.107 X_{3}+0.420 X_{4}+0.998 X_{5}
$$

$Z=$ Overall index

$\mathrm{X}_{1}=$ Working capital/total assets

$\mathrm{X}_{2}=$ Retained earnings/total assets

$\mathrm{X}_{3}=$ Earnings before interest and taxes/total assets

$\mathrm{X}_{4}=$ Book value equity/book value of total liabilities

$\mathrm{X}_{5}=$ Sales/total assets

With the following criteria: 
1. If the value of $Z<1.21$ is a bankrupt company.

2. If the value of $1.23<Z<2.90$ is gray area (it cannot be determined whether the company is healthy or has bankruptcy).

3. if the value of $Z>2.90$ is a company that is not bankrupt.

\subsection{Measurement of abnormal return}

The performance measured in this study is the stock price of a financial distress company that implements restructuring of mergers \& acquisitions, management turnover (CEO turnover), and employee lay-off (downsizing) as a form of strategy turnaround. The measuring instrument used to measure performance is Abnormal Return. Event studies analyze abnormal returns from companies that may occur around the announcement of an event.

- Abnormal Return

$$
\mathrm{AR}_{i, t}=\mathrm{R}_{i, t}-\mathrm{E}\left[\mathrm{R}_{i, t}\right]
$$

Description:

$\operatorname{Ar}_{i, t}$ : Abnormal return of the i-securities in the $t$-period of events

$\mathrm{R}_{i, t}:$ The actual return that occurs for the 1 st securities in the $t$-event period.

$E\left[R_{i, t}\right]$ : Return of the 1st securities expectation for the $t$-event period

- Actual Return

Where the formula is actual return (Jogiyanto, 2010: 64) are:

$$
R_{i, t}=\frac{P_{i, t}-P_{i, t-1}}{i, t-1}
$$

Description:

$\mathrm{R}_{i, t}$ : Daily stock return of securities $i$ at period $t$

$\mathrm{P}_{i, t}$ : Daily securities stock price $i$ at period $t$

$\mathrm{P}_{i, t-1}$ : securities daily share price $i$ in period $t-1$

- Market-adjusted model

This study uses a market-adjusted model to determine the expected return (Jogiyanto, 2010: 76) with the formula:

$$
E\left[R_{i, t}\right]=R_{M, i, t}
$$




\section{Description:}

$\mathrm{E}\left[\mathrm{R}_{i, t}\right]$ : Expected Return securities $i$ in the $t$ period of event

$\mathrm{R}_{M, i, t}:$ Return Market from the 1st securities in the period $t$-event

- Market return

Formula return Market (Jogiyanto, 2010: 76) is:

$$
\mathrm{R}_{M, t}=\frac{\mathrm{IHSG}_{t}-\mathrm{IHSG}_{, t-1}}{\mathrm{IHSG}_{, t-1}}
$$

Note:

$\mathrm{R}_{m t}:$ Return market

$\mathrm{IHSG}_{t}: \mathrm{IHSG}_{t}$ period $t$

$\mathrm{IHSG}_{t-1}: \mathrm{IHSG}_{t-1}$ period $t-1$

Results of calculation of abnormal returns that have been known, the average is calculated. Average Abnormal Return (AAR) by using a formula (Jogiyanto, 2010: 96):

$$
A A R t=\frac{\sum A R_{1, t}}{n}
$$

Description:

$\mathrm{AAR}_{t}$ : Average abnormal return of securities I period estimated $\sum A R_{i, t}$ : Number of abnormal return securities I in the period event $n$ : Number of companies

\subsection{Event window}

This study uses the company's daily stock data which is sampled in the study during the observation period. The observation period used in this study was 21 exchange days, namely 10 days before the event $(t-10), 1$ day when the event occurred $(t=0)$, and 10 days after the announcement event $(t+10)$. The 21-day event period is taken in the hope that the market reaction can already be seen during that period.

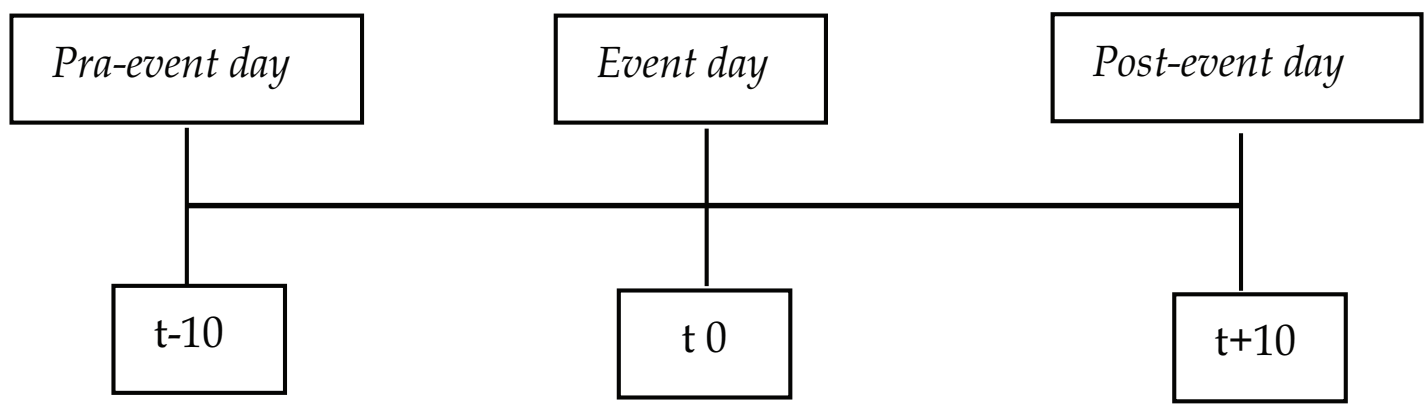




\subsection{Hypothesis test}

We used one sample t-test to test hypothesis 1, this technique is used to test whether certain values differ significantly or not with the average of a sample (Ghazali, 2013: 97). This test is intended to analyze whether there are significant abnormal stock returns in the period surrounding the announcement of mergers and acquisitions, CEO turnover, and downsizing. The test criteria are at the $5 \%$ significance level by looking at whether the probability value is smaller or greater than $5 \%$. There will be a difference if the probability value is smaller by $5 \%(p<5 \%)$, and if the probability value is greater than $5 \%$ (sig $t \geq 5 \%$ ) then there is no difference in mean.

Hypothesis 2 states that there was a differences in average abnormal returns before and after the announcement of acquisition mergers, CEO turnover, and downsizing. Hypothesis 2 was tested by comparing average abnormal returns 10 days before and 10 days after the date of the event. Normality test is used to find out whether the variable data to be tested in the study is normal or not (Ghazali, 2013: 154). This is needed to determine the testing tool that will be used in hypothesis testing, whether in the form of a parametric test or non-parametric test. The tool used in testing normality is the Kolmogorov-Smirnov test. Kolmogorov-Smirnov test with a value of $\alpha=5 \%$ or 0.05 which the test uses SPSS version 22, with the following criteria:

1. If the significance value is $>0.05$, the data is normally distributed

2. If the significance value is $<0.05$, the data is not normally distributed

If the data is normally distributed, then a statistical test is performed using the PairedSample $T$-Test, if the data is not normally distributed, the Wilcoxon Matched Signed Rank test is used with the criteria if sig. (2-tailed) $>0.05$, then it's accepted, and if sig. (2-tailed) $<0.05$, then it's rejected.

\section{Result and Discussion}

\subsection{Normality test}

In this study normality tests were carried out using the Kolmogorov-Smirnov test. The following are the results of the normality test.

Based on Table 3 results normality test using the Kolmogorov-Smirnov test, the value of Asymp. Sig. (2-tailed) is 0.200 which is greater than the significance value of $0.05(\alpha=$ 
TABLE 3: Results of Normality test.

\begin{tabular}{|l|c|c|}
\hline Variable & Significant & Description \\
\hline Merger \& Acquisition Before & 0.200 & Normal \\
\hline Merger \& Acquisition After & 0.200 & Normal \\
\hline CEO Turnover Before & 0.200 & Normal \\
\hline CEO Turnover After & 0.200 & Normal \\
\hline Employee Lay-Off Before & 0.200 & Normal \\
\hline Employee Lay-Off After & 0.200 & Normal \\
\hline
\end{tabular}

$5 \%)$ so that the residual data is normally distributed. This shows that the data has fulfilled the aspect of normality.

\subsection{Abnormal return for turnarouund strategy announcement}

The first hypothesis, $\mathrm{H}_{1 a}$ states 'There is a significant market reaction around the date of the announcement of mergers \& acquisitions in companies financial distress. Table 4 shows that there is abnormal return a significant with a $5 \%$ significance level during the period of the event, namely on days -2 and -1 . Abnormal returns with positive values occur on days 2 and -1 . This is based on $t_{\text {count }}$ on days $t-2$ (6.425) and $t-1$ (12.425) greater than $t_{\text {table }}(2.920)$. These results indicate that the capital market reacts to the announcement of mergers and acquisitions of manufacturing companies that experience financial distress as indicated by the presence of abnormal returns significant positive. Thus, $\mathrm{H}_{0 i s}$ rejected and $\mathrm{H}_{1 a}$ received, so it can be concluded that the merger and acquisition of manufacturing companies experiencing financial distress has information content.

$\mathrm{H}_{1 b}$ states 'There is a significant market reaction around the announcement date of the change of CEO (CEO turnover) on the company's financial distress'. Based on Table 5 found that abnormal return at the time of the event was announced at 0.022 with a value of $t_{\text {count }}$ of 0.0823 smaller than $t_{\text {table }} 2.132$ this indicates that there is no significant difference in abnormal return of shares between before and after the announcement is CEO turnover made, so that $\mathrm{H}_{0}$ is accepted and $\mathrm{H}_{1 b}$ is rejected. During the 10 days before and 10 days after there is no difference abnormal return a significant occurs. The market shows a positive reaction but is not significant at the time the event is announced with an abnormal return of 0.022 .

$\mathrm{H}_{1 c}$ states 'There is a significant market reaction around the announcement date of the employee-lay off (downsizing) in the financial distress company'. Based on Table 5 there is an abnormal return negative but it is not significant on the day the event was announced which is equal to -0.007 . The value of $t_{\text {arithmetic }}(-1.104)$ is smaller with the value 
TABLE 4: Abnormal return of mergers \& acquisitions.

\begin{tabular}{|c|c|c|c|}
\hline Day & AAR & t-count & Description \\
\hline$t-10$ & $-0,016$ & $-1,106$ & $\mathrm{H}_{0}$ accepted \\
\hline$t-9$ & $-0,008$ & $-1,143$ & $\mathrm{H}_{0}$ accepted \\
\hline$t-8$ & $-0,003$ & $-0,314$ & $\mathrm{H}_{0}$ accepted \\
\hline$t-7$ & $-0,002$ & $-0,150$ & $\mathrm{H}_{0}$ accepted \\
\hline$t-6$ & $-0,017$ & $-1,604$ & $\mathrm{H}_{0}$ accepted \\
\hline$t-5$ & 0,008 & 0,819 & $\mathrm{H}_{0}$ accepted \\
\hline$t-4$ & 0,030 & 0,901 & $\mathrm{H}_{0}$ accepted \\
\hline$t-3$ & $-0,002$ & $-0,111$ & $\mathrm{H}_{0}$ accepted \\
\hline$t-2$ & 0,006 & 6,425 & $\mathrm{H}_{0}$ rejected \\
\hline$t-1$ & 0,011 & 12,425 & $\mathrm{H}_{0}$ rejected \\
\hline to & $-0,027$ & $-1,034$ & $\mathrm{H}_{0}$ accepted \\
\hline$t+1$ & 0,008 & 0,534 & $\mathrm{H}_{0}$ accepted \\
\hline$t+2$ & $-0,003$ & $-1,134$ & $\mathrm{H}_{0}$ accepted \\
\hline$t+3$ & $-0,011$ & $-0,815$ & $\mathrm{H}_{0}$ accepted \\
\hline$t+4$ & 0,002 & 0,570 & $\mathrm{H}_{0}$ accepted \\
\hline$t+5$ & $-0,004$ & $-0,473$ & $\mathrm{H}_{0}$ accepted \\
\hline$t+6$ & 0,011 & 3,024 & $\mathrm{H}_{0}$ accepted \\
\hline$t+7$ & 0,012 & 1,182 & $\mathrm{H}_{0}$ accepted \\
\hline$t+8$ & 0,003 & 0,320 & $\mathrm{H}_{0}$ accepted \\
\hline$t+9$ & 0,003 & 0,540 & $\mathrm{H}_{0}$ accepted \\
\hline$t+10$ & 0,006 & 0,418 & $\mathrm{H}_{0}$ accepted \\
\hline
\end{tabular}

of $\mathrm{t}_{\text {table }}(2.015)$ so that there is no abnormal return significant between 10 days before and 10 days after the announcement. This shows that $\mathrm{H}_{0}$ is accepted and $\mathrm{H}_{1 c}$ is rejected.

The second test is done by doing a different test to test the hypothesis that states that 'There are a differences in average abnormal returns after and before the announcement of mergers \& acquisitions, CEO turnover, and employee lay-off (downsizing) in the financial distress company'. To test $\mathrm{H}_{2 i s}$ done by comparing the average abnormal return 10 days before and 10 days after the announcement of events of mergers \& acquisitions, CEO Turnover, and employee lay-off (downsizing). The results of the normality test in Table 6 show that the data is normally distributed which is indicated by a probability value greater than the 0.05 level, then the data is normally distributed. Because the data is normally distributed, the will be used paired samples $t$-test $t$. Results of paired samples $t$-test can be seen in Table 7.

Based on Table 7, it can be seen that the significance value of before and after mergers \& acquisitions is 0.722 , CEO significance value Turnover before and after is 0.148 at 0.148 , and the significance value of downsizing before and after is 0.143 . In all announcements the restructuring strategy shows a significance level greater than 0.05 , 
TABLE 5: Abnormal return of CEO turnover.

\begin{tabular}{|c|c|c|c|}
\hline Day & AAR & t-count & Description \\
\hline$t-10$ & 0,041 & 0,781 & $\mathrm{H}_{0}$ accepted \\
\hline$t-9$ & $-0,013$ & $-0,837$ & $\mathrm{H}_{0}$ acceptec \\
\hline$t-8$ & $-0,036$ & $-1,081$ & $\mathrm{H}_{0}$ acceptec \\
\hline$t-7$ & 0,046 & 0,962 & $\mathrm{H}_{0}$ acceptec \\
\hline$t-6$ & $-0,005$ & $-0,687$ & $\mathrm{H}_{0}$ acceptec \\
\hline$t-5$ & 0,007 &,- 266 & $\mathrm{H}_{0}$ accepted \\
\hline$t-4$ & 0,010 & 1,475 & $\mathrm{H}_{0}$ acceptec \\
\hline$t-3$ & $-0,016$ & $-0,887$ & $\mathrm{H}_{0}$ acceptec \\
\hline$t-2$ & $-0,002$ & $-0,180$ & $\mathrm{H}_{0}$ acceptec \\
\hline$t-1$ & $-0,003$ & $-0,174$ & $\mathrm{H}_{0}$ acceptec \\
\hline to & 0,022 & 0,823 & $\mathrm{H}_{0}$ acceptec \\
\hline$t+1$ & $-0,015$ & $-0,767$ & $\mathrm{H}_{0}$ accepted \\
\hline$t+2$ & $-0,025$ & $-2,756$ & $\mathrm{H}_{0}$ acceptec \\
\hline$t+3$ & $-0,024$ & $-1,521$ & $\mathrm{H}_{0}$ accepted \\
\hline$t+4$ & $-0,004$ & $-0,279$ & $\mathrm{H}_{0}$ acceptec \\
\hline$t+5$ & 0,025 & 1,395 & $\mathrm{H}_{0}$ accepted \\
\hline$t+6$ & $-0,002$ & $-0,225$ & $\mathrm{H}_{0}$ acceptec \\
\hline$t+7$ & 0,006 & 0,562 & $\mathrm{H}_{0}$ acceptec \\
\hline$t+8$ & $-0,016$ & $-2,252$ & $\mathrm{H}_{0}$ acceptec \\
\hline$t+9$ & $-0,020$ & $-1,1739$ & $\mathrm{H}_{0}$ acceptec \\
\hline$t+10$ & $-0,003$ & $-0,358$ & $\mathrm{H}_{0}$ acceptec \\
\hline
\end{tabular}

thus accepting $\mathrm{H}_{0}$ which states that there is no difference in average abnormal returns between before and after the event is announced

Based on Table 4, it can be seen that the market reacts to information related to the announcement of mergers \& acquisitions quickly and not prolonged in absorbing abnormal returns. Investors tend to assume that the information contained therein is good news, in other words investors have the expectation that after a merger and acquisition the company will get better in the hope of being able to distribute higher dividends. Abnormal returns that are significantly positive are found 2 days before the announcement day can be caused by an information leak. The leakage of information in question is that the market knows the information about mergers \& acquisitions before the event occurs.

As we know, in article 123 section (1) of Law Of The Republic Of Indonesia No.40 of 2007 concerning Limited Ability Companies, the company is obliged to prepare a merger plan which will then be approved by the board of commissioners of each company. The results of the proposed merger plan will be submitted at a general meeting of shareholders (GMS). Article 127 section (2) of Law Of The Republic Of Indonesia No.40 of 2007 
TABLE 6: Abnormal return of employee lay-off.

\begin{tabular}{|c|c|c|c|}
\hline Day & AAR & t-count & Description \\
\hline$t-10$ & 0,009 & 1,237 & $\mathrm{H}_{0}$ accepted \\
\hline$t-9$ & 0,022 & 1,481 & $\mathrm{H}_{0}$ accepted \\
\hline$t-8$ & 0,008 & 0,274 & $\mathrm{H}_{0}$ accepted \\
\hline$t-7$ & 0,002 & 0,051 & $\mathrm{H}_{0}$ accepted \\
\hline$t-6$ & $-0,034$ & $-1,114$ & $\mathrm{H}_{0}$ accepted \\
\hline$t-5$ & 0,036 & 1,540 & $\mathrm{H}_{0}$ accepted \\
\hline$t-4$ & 0,019 & 0,682 & $\mathrm{H}_{0}$ accepted \\
\hline$t-3$ & 0,016 & 1,809 & $\mathrm{H}_{0}$ accepted \\
\hline$t-2$ & $-0,002$ & $-0,131$ & $\mathrm{H}_{0}$ accepted \\
\hline$t-1$ & $-0,008$ & $-0,417$ & $\mathrm{H}_{0}$ accepted \\
\hline to & $-0,007$ & $-1,104$ & $\mathrm{H}_{0}$ accepted \\
\hline$t+1$ & $-0,016$ & $-1,061$ & $\mathrm{H}_{0}$ accepted \\
\hline$t+2$ & 0,010 & 1,080 & $\mathrm{H}_{0}$ accepted \\
\hline$t+3$ & $-0,015$ & $-1,624$ & $\mathrm{H}_{0}$ accepted \\
\hline$t+4$ & $-0,011$ & $-1,145$ & $\mathrm{H}_{0}$ accepted \\
\hline$t+5$ & 0,017 & 1,158 & $\mathrm{H}_{0}$ accepted \\
\hline$t+6$ & 0,001 & 0,103 & $\mathrm{H}_{0}$ accepted \\
\hline$t+7$ & $-0,009$ & $-0,851$ & $\mathrm{H}_{0}$ accepted \\
\hline$t+8$ & 0,000 & 0,021 & $\mathrm{H}_{0}$ accepted \\
\hline$t+9$ & 0,000 & 0,000 & $\mathrm{H}_{0}$ accepted \\
\hline$t+10$ & $-0,012$ & 0,085 & $\mathrm{H}_{0}$ accepted \\
\hline
\end{tabular}

TABLE 7: Result of paired samples $t$-test.

Variable
Merger \& Acquisitions
Before-After
CEO Turnover
Before \& After
Employee Lay-Off
Before-After

\begin{tabular}{c}
\hline Significant \\
\hline 0.722 \\
\hline 0.148 \\
\hline 0.143 \\
\hline
\end{tabular}

\begin{tabular}{l} 
Description \\
Not Significant \\
Not Significant \\
\hline Not Significant
\end{tabular}

concerning Limited Ability Companies, the board of directors must announce at least one daily newspaper regarding the planned merger within a maximum period of 30 days before the GMS is held. The results of the merger must be announced by the company at least on one daily newspaper within the date of the merger \& acquisition has been completed based on Article 133 section (3) of Law Of The Republic Of Indonesia No.40 of 2007 concerning Limited Ability Companies. This causes information about planned mergers and acquisitions to be received by investors before the event is announced, so that investors have prepared themselves before the day the event was announced. 
The results of this study support research conducted by Kam, Citron, \& Muradoglu, (2010) which shows that among 4 strategies observed mergers \& acquisitions, asset sales, management restructuring, and debt restructuring investors react to merger and acquisition strategies and research conducted by Rani, Yadav, \& Jain, (2013) and Gubbi et al, (2010) who found that there was a significant positive market reaction when the company announced mergers and acquisitions during the research observation period.

Based on Table 5, the CEO turnover announcement can be seen that the market shows a positive reaction but is not significant at the time the event is announced. The market reacts positively but insignificantly indicates that the event is accepted by investors as good news in the hope that a new CEO turnover can bring new changes and improve the company's financial performance in the future. The absence of a significant reaction by the market can be caused by an information leak. The leakage of information referred to in this case is that plans for CEO changes will be included in the agenda of the general meeting of shareholders (GMS) so that investors will first receive information before the event occurs.

Pursuant to Article 79 section (1) of Law Of The Republic Of Indonesia No.40 of 2007 concerning Limited Ability Companies, the board of commissioners is obliged to call a GMS to investors starting no more than 15 days before the date of the GMS request is executed accompanied by a registered letter of reason for the GMS. This is reinforced in Article 4 section (3) of the Financial Service Authority number 32/POJK.04/2014 of 2014 concerning plan dan holding of General meeting of shareholders of public companies, explaining that the GMS announcement must be held in 15 days before the date of the GMS request is announced and its need to be announced at least through 1 (one) national daily newspaper, the Indonesia Stock Exchange's official website, and the company's official website in Indonesian and foreign languages.

Based on Table 6 it can be seen that the market does not react to the announcement of employee lay-off (downsizing). The results of one sample $t$-test showed that abnormal returns on day 0 tended to be negative but not significant. This indicates that the market responds to events that occur as sources of information but not strong. An insignificant negative response is a form that investors value downsizing as bad news. Employee lay-off measures or in other words the termination of employment (PHK) taken by the company indicates that the company is in a state of financial difficulties and in an effort to overcome the situation. This information sends a signal to investors that the company will distribute less investment results than before so investors react negatively but insignificantly. 
This result is in line with research conducted by Lin, Lee, \& Gibbs (2008) and Elayan, Swales, Maris, \& Scott (1998) that investors react negatively but are not statistically significant to the announcement of company employee dismissal. The dismissal of employees shows the risk of higher business failures and companies in poor operational performance which will certainly have an impact on future investment opportunities.

Based on Table 7 Paired Samples $T$-Test results show that there is no difference in average abnormal returns in the announcement of mergers \& acquisitions, CEO turnover, and employee lay-off (downsizing). Leakage of information causes a response from the market, but the response that is not so strong results in the average abnormal return before and after the announcement of mergers \& acquisitions, CEO turnover, and downsizing does not have a statistically significant difference. Fluctuations in average abnormal returns in the event period reflect uncertainty caused by various market surprises that can occur around the period of the announcement event. The absence of a prolonged market reaction can also be the cause of the absence of differences before and after the event because the information received by the market is relatively the same. In addition investors also assess based on the company's performance, not only from the events that occur around.

\section{Acknowledgment}

The authors would like to thank Allah SWT because he is the best disposer of their affairs. And then, they would to thank all their beloved lecturers Dr. Eni Wuryani, SE., M.Si; Dr. Hariyati, Ak., M.Si., CA., CMA; and Lintang Venusita, SE., Ak., M.Si., CA for their kindness in guiding them in finishing their research. They are also thankful to their family and friends for all their support.

\section{References}

[1] Altman, E. I. (2000). Predicting financial distress of companies: revisiting the Z-Score and ZETA models. Handbook of Research Methods and Applications in Empirical Finance, pp. 428-456. Retrieved from: https://doi.org/10.4337/9780857936097. 00027

[2] Almilia, L. S. and Kristijadi, E. (2014). Analisis rasio keuangan untuk memprediksi kondisi financial distress perusahaan manufaktur yang terdaftar di bursa efek Jakarta. Jurnal Akuntansi \& Auditing Indonesia, vol. 1, no. 2, pp. 52-62. 
[3] Arogyaswamy, K., Barker, V. L., and Ardekani, M. Y. (1995). Firm turnarounds: An integrative two-stage model. Journal of Management Studies, vol. 32, no. 4, pp. 493525.

[4] Ashayeri, J., Ma, N., and Sotirov, R. (2014). Supply chain downsizing under bankruptcy: A robust optimization approach. International Journal of Production Economics, vol. 154, pp. 1-15.

[5] Auqie, V. (2013). Dampak Merger dan Akuisisi Terhadap Abnormal Return dan Kinerja Keuangan Bidder Firm di Sekitar Tanggal Pengumuman Merger dan Akuisisi Pada Perusahaan yang Terdaftar di Bursa Efek Indonesia Periode 2009-2012. Jurnal Calyptra, vol. 2, no. 2, pp. 1-16.

[6] Chan, P. S. (1993). Management Decision managing successful turnarounds: Lessons from Global Companies. Management Decision Journal of Business Strategy European Business Review Iss Research in the Sociology of Work Management Decision, vol. 31, no. 3, pp. 243-262.

[7] Dahya, J. and McConnell, J. J. (2005). Outside directors and corporate board decisions. Journal of Corporate Finance, vol. 11, no. 1-2), pp. 37-60.

[8] de Young, R., Evanoff, D. D., and Molyneux, P. (2009). Mergers and acquisitions of financial institutions: A review of the post-2000 literature. Journal of Financial Services Research, vol. 36, no. 2, pp. 87-110.

[9] Dedman, E. and Lin, S. W. (2002). Shareholder wealth effects of CEO departures: Evidence from the UK. Journal of Corporate Finance, vol. 8, pp. 81-104.

[10] Denis, D. J. and Kruse, T. A. (2000). Managerial discipline and corporate restructuring following performance declines. Journal of Financial Economics, vol. 55, no. 3, pp. 391-424.

[11] Elayan, F. A., Swales, G. S., Maris, B. A., et al. (1998). Market reactions, characteristics, and the effectiveness of corporate layoffs. Journal of Business Finance and Accounting, vol. 25, no. 3-4, pp. 329-351.

[12] Gilson, S. C. (1990). Bankruptcy, boards, banks, and blockholders. Evidence on changes in corporate ownership and control when firms default. Journal of Financial Economics, vol. 27, no. 2, pp. 355-387.

[13] Gopinath, C. (1991). Turnaround: Recognizing decline and initiating intervention. Long Range Planning, vol. 24, no. 6, pp. 96-101.

[14] Grinyer, P. H., Mayes, D., and McKiernan, P. (1990). The sharpbenders: Achieving a sustained improvement in performance. Long Range Planning, vol. 23, no. 1, pp. 116125. 
[15] Gubbi, S. R., Aulakh, P. S., Ray, S., et al. (2010). Do international acquisitions by emerging-economy firms create shareholder value the case of Indian firms. Journal of International Business Studies, vol. 41, no. 3, pp. 397-418.

[16] Gugler, K., Mueller, D. C., Yurtoglu, B. B., et al. (2003). The effects of mergers: An international comparison. International Journal of Industrial Organization, vol. 21, no. 5, pp. 625-653.

[17] Hofer, C. W. (1980). Turnaround strategies. Journal of Business Strategy, vol. 1, no. 1, p. 19.

[18] Jogiyanto, H. (2010). Event Study: Testing Capital Market Reactions Due to an Event [Studi Peristiwa: Menguji Reaksi Pasar Modal Akibat Suatu Peristiwa] (first edition). Yogyakarta: BPFE-Yogyakarta.

[19] Kam, A., Citron, D., and Muradoglu, G. (2010). Financial distress resolution in China Two case studies. Qualitative Research in Financial Markets, vol. 2, no. 2, pp. 46-79.

[20] Kang, J. and Shivdasani, A. (1996). Does the Japanese governance system enhance shareholder wealth? Evidence from the stock-price effects of top management turnover. The Review of Financial Studies, vol. 9, no. 4, pp. 1061-1095.

[21] Lin, B., Lee, Z.-H., and Gibbs, L. G. (2008). Operational restructuring: Reviving an ailing business. Management Decision, vol. 46, no. 4, pp. 539-552.

[22] Maheshwari, S. K. (2000). Organizational decline and turnaround management: A contigency framework. The Journal for Decision Makers, vol. 25, no. 4, pp. 39-50.

[23] Mamduh, H. M. and Halim, A. (2007). Financial Statement Analysis [Analisis Laporan Keuangan] (third edition). Yogyakarta: STIE YKPN.

[24] Mitchell, M. L. and Mulherin, J. H. (1996). The impact of industry shocks on takeover and restructuring activity. Journal of Financial Economics, vol. 41, no. 2, pp. 193-229.

[25] Mutamimah. (2009). Tunneling or value added in strategy [Tunneling Atau Value Added Dalam Strategi]. Jurnal Manajemen Teori Dan Terapan, vol. 2, no. 2, pp. $161-$ 182.

[26] O'Neill, H. M. (1986). Turnaround and recovery: What strategy do you need? Long Range Planning, vol. 19, no. 1, pp. 80-88.

[27] Pearce II, J. A. and Robbins, D. K. (1994). Entrepreneural recovery strategies of small market share manufacturers. Journal of Business Venturing, vol. 9, pp. 91-108.

[28] Pearce II, J. A. and Robbins, K. (1993). Toward improve theory and research on business turnaround. Journal of Management, vol. 19, no. 3, pp. 613-636.

[29] Platt, H. D. and Platt, M. B. (2002). Predicting corporate financial distress: Reflections on choice-based sample bias. Journal of Economics and Finance, vol. 26, no. 2, pp. 184-199. 
[30] Rani, N., Yadav, S. S., and Jain, P. K. (2013). Market response to the announcement of mergers and acquisitions: An empirical study from India. Vision: The Journal of Business Perspective, vol. 17, no. 1, pp. 1-16.

[31] Santana, M., Valle, R., and Galan, J. L. (2017). Turnaround strategies for companies in crisis: Watch out the causes of decline before firing people. BRQ Business Research Quarterly, vol. 20, no. 3, pp. 206-211.

[32] Schendel, D., Patton, G. R., and Riggs, J. (1976). Corporate turnaround strategies: A study of profit decline and recovery. Journal of General Management, vol. 3, no. 3, pp. 3-12.

[33] Suchard, J. A., Singh, M., and Barr, R. (2001). The market effects of CEO turnover in Australian firms. Pacific Basin Finance Journal, vol. 9, no. 1, pp. 1-27.

[34] Suhfriahtiningsih, E. (2017). Faktor-Faktor Yang Mempengaruhi Keberhasilan Proses Turnaround Pada Perusahaan Manufaktur. Jurnal IImu Dan Riset Akuntansi, vol. 6, no. 6 , pp. 1-18.

[35] Telaumbanua, B. I. K. and Sumiyana. (2008). Event study: Pengumuman laba terhadap reaksi pasar modal (Studi Empiris, Bursa Efek Indonesia 2004-2006). Jurnal Manajemen Teori Dan Terapan, vol. 1, no. 3, pp. 106-127.

[36] Tourtellot, P. L. (2004). Successful corporate turnarounds: Operational expertise makes the difference. The Journal of Private Equity, vol. 7, no. 4, pp. 68-71.

[37] Vestari, M. and Farida, D. N. (2013). Analisis Rasio-Rasio Dan Ukuran Keuangan, Prediksi Financial Distress, Dan Reaksi Investor. Akrual, vol. 5, no. 1, pp. 26-44.

[38] Whiting, R. H. and Miller, J. C. (2008). Voluntary disclosure of intellectual capital in New Zealand annual reports and the "hidden value." Journal of Human Resource Costing \& Accounting, vol. 12, no. 1, pp. 26-50.

[39] Financial Service Authority number 32/POJK.04/2014 of 2014 concerning plan dan holding of general meeting of shareholders of public companies.

[40] Law of the Republic of Indonesia No. 40 of 2007 concerning Limited Ability Companies. 